\title{
Hellea balneolensis gen. nov., sp. nov., a prosthecate alphaproteobacterium from the Mediterranean Sea
}

Correspondence
Philippe Lebaron
philippe.lebaron@obs-banyuls.fr

The phylum Proteobacteria is one of the 24 phyla of the domain Bacteria described in Bergey's Manual of Systematic Bacteriology, 2nd edn (Garrity \& Holt, 2001). To date, more than 200 genera have been described, making this one of the largest bacterial phyla. Members of this group are widely distributed in nature and are physiologically and metabolically diverse. The phylum Proteobacteria is currently divided into five classes, the Alphaproteobacteria, Betaproteobacteria, Gammaproteobacteria, Deltaproteobacteria and Epsilonproteobacteria, all of which have been defined exclusively on the basis of $16 \mathrm{~S}$ rRNA gene sequence analysis (Garrity \& Holt, 2001). At present, the class

†Present address: UMR6197, Laboratoire de Microbiologie des Environnements Extrêmes, IUEM, Technopôle Brest-Iroise, F-29280 Plouzané, France.

Abbreviation: TBSA, tuberculostearic acid.

The GenBank/EMBL/DDBJ accession number for the 16S rRNA gene sequence of strain $26111 / \mathrm{A0} 2 / 215^{\top}$ is AY576758.

A graph showing the effect of temperature on the maximum growth rate of strain $26 \mathrm{III} / \mathrm{A0} 2 / 215^{\mathrm{T}}$ is available as supplementary material with the online version of this paper.
Alphaproteobacteria Garrity et al. 2006 (Garrity et al., 2005a) is composed of seven orders: Caulobacterales Henrici and Johnson 1935, Kordiimonadales Kwon et al. 2005, Rhodobacterales Garrity et al. 2006 (Garrity et al., 2005b), Rhodospirillales Pfenning and Trüper 1971, Rickettsiales Gieszczykiewicz 1939, Rhizobiales Kuykendall 2006 (Kuykendall, 2005) and Sphingomonadales Yabuuchi and Kosako 2006 (Yabuuchi \& Kosako, 2005). Marine species make up more than half of the species of the Alphaproteobacteria described to date.

Some confusion is being caused at present by the different taxonomic placement of the 'stalked' bacteria. While Lee et al. (2005) place the members of the genera Hyphomonas, Oceanicaulis, Hirschia and Maricaulis in a new family, the Hyphomonadaceae, within the order Caulobacterales (which includes members of the family Rhodobacteraceae), Garrity et al. (2005a) have placed members of these genera within the family Rhodobacteraceae, within the order Rhodobacterales, leaving the members of the family Caulobacteraceae within the order Caulobacterales. This situation is particularly unsatisfactory since use of the 
name of the order Caulobacterales alone does not give unambiguous information on which taxa are to be included within it. Furthermore, Lee et al. (2005) dealt with the taxonomy of the family Rhodobacteraceae before the name was validly published (Garrity et al., 2006). Paradoxically Lee et al. (2005) created a new family, the family Hyphomonadaceae, with the type defined as the genus Hyphomonas, a taxon specifically included in the taxon proposed by Garrity et al. (2005b) as the family Rhodobacteraceae. Based on the principle of priority, the family proposed by Garrity et al. (2005b) must be named after the earliest validly published family name, which is the family Hyphomonadaceae. The family name Rhodobacteraceae Garrity et al. 2006 may be used only if specifically defined to exclude the type genus of the family Hyphomonadaceae. It should be noted that members of the genera Woodsholea (Abraham et al., 2004) and Robiginitomaculum (Lee et al., 2007) should be included in the family Hyphomonadaceae Lee et al. 2007.

The members of the families Hyphomonadaceae and Caulobacteraceae include organisms that share the particular feature of being appendaged (Poindexter, 1981; Abraham et al., 1999; Weiner et al., 2000; Strömpl et al., 2003). As indicated by their vernacular name (in Latin, caulis means stalk), these 'caulobacteria' bear one or several stalks, socalled prosthecae. These stalks are cytoplasm extrusions that undoubtedly play a role in attachment. As a result, they increase significantly the surface-to-volume ratio of the cells. Consequently, they have often been interpreted as an evolutionary adaptation to life in oligotrophic waters. Most genera of the families Hyphomonadaceae and Caulobacteraceae (i.e. members of the genera Hyphomonas, Caulobacter, Asticcacaulis, Phenylobacterium, Hirschia, Robiginitomaculum, Woodsholea, Maricaulis, Oceanicaulis and Brevundimonas) are widely distributed in marine environments (Anast \& Smit, 1988) and especially (but not exclusively) in oligotrophic waters. They are believed to play an important role in the mineralization of dissolved organic matter (Abraham et al., 1999).

In this study, a novel marine caulobacterium is described. Based on the results of a polyphasic taxonomic analysis, strain $26 \mathrm{III} / \mathrm{A} 02 / 215^{\mathrm{T}}$ represents a novel species and genus.

In September 2001, a coastal water sample was collected in the bay of Banyuls-sur-mer $\left(42^{\circ} 29^{\prime} \mathrm{N}^{\circ} 08^{\prime} \mathrm{E}\right)$, on the Mediterranean coast of France. A sample from the surface microlayer was spread on a marine agar 2216 (MA; Difco) plate and then incubated at $25{ }^{\circ} \mathrm{C}$. After 2 weeks, a redcoloured colony was picked, purified by repeated streaking on MA plates and referenced as strain 26III/A02/215 (Agogué et al., 2005). Stock cultures were stored at $-80{ }^{\circ} \mathrm{C}$ in marine broth 2216 (MB; Difco) supplemented with $5 \%$ $(\mathrm{v} / \mathrm{v})$ DMSO or $35 \%(\mathrm{v} / \mathrm{v})$ glycerol until characterization.

Both strands of the almost-complete 16S rRNA gene (1412 bp) of the strain were sequenced from a single colony, as described elsewhere (Agogue et al., 2005). This sequence was compared to those in available databases by use of the BLAST program (Altschul et al., 1990) and then aligned to its nearest neighbours using the CLUSTAL_X program (Thompson et al., 1997). Alignments were refined manually using the SEAVIEW program (Galtier et al., 1996). Phylogenetic trees were constructed by using the PHYLIP software version 3.63 (http://evolution.genetics.washington.edu/phylip/getme.html) on the basis of evolutionary distance (neighbour-joining method with Jukes and Cantor corrections) (Saitou \& Nei, 1987) and maximum-likelihood (Felsenstein, 1981). The robustness of the inferred topologies was assessed by bootstrap analyses based on 1000 bootstrap resamplings for the neighbour-joining and 100 replications for the maximum-likelihood method (Felsenstein, 1985). The 16S rRNA gene-based analysis located the strain $261 \mathrm{II} / \mathrm{A} 02 / 215^{\mathrm{T}}$ within the class Alphaproteobacteria, in the bacterial domain. The results of different phylogenetic reconstructions performed with different treeing algorithms located the novel isolate within the Hyphomonas-Hirschia-Robiginitomaculum branch, amongst the marine caulobacteria of the family Hyphomonadaceae (Lee et al., 2005), order Caulobacterales (Fig. 1). Within this branch, the novel isolate clustered with the recently described genus Robiginitomaculum (Lee et al., 2007), sharing $93.9 \% 16 \mathrm{~S}$ rRNA gene sequence similarity with the type strain of the only species of this genus. The 16S rRNA gene sequence similarity between strain 26III/ $\mathrm{A} 02 / 215^{\mathrm{T}}$ and representatives of the genera Hyphomonas and Hirschia ranged from 89 to $92 \%$.

The DNA G+C content was determined by the Identification Service of the DSMZ by HPLC analysis of deoxyribonucleosides as described by Mesbah et al. (1989). The $\mathrm{G}+\mathrm{C}$ content of strain 26III/A02/215 $5^{\mathrm{T}}$ was $46.8 \mathrm{~mol} \%$. Thus, it differed by more than $10 \mathrm{~mol} \%$ from the DNA G+C content of its closest relative Robiginitomaculum antarcticum $(60.3 \mathrm{~mol} \%)$. Clearly, this large difference in the DNA base ratio, together with the level of $16 \mathrm{~S}$ rRNA gene sequence similarity, suggest that strain $261 \mathrm{II} / \mathrm{A} 02 / 215^{\mathrm{T}}$ belongs to a novel genus (RossellóMora \& Amann, 2001).

Colonies on MA were circular, smooth, brilliant and convex with an entire edge and were intensely pigmented brick-red. After 1 week of incubation, colonies were about $1 \mathrm{~mm}$ in diameter. Morphological characteristics of the cells were determined by light microscopy (Olympus AX70) and by transmission electron microscopy (Hitachi H-7500) after negative staining with uranyl acetate (Raguénès et al., 1997). Briefly, cells of strain 26III/A02/ $215^{\mathrm{T}}$ stained Gram-negative and were thin, straight to curved rods bearing one polar stalk (Fig. 2). Cells bearing several lateral stalks were occasionally observed. Midexponential phase cells were $2.70-5.60 \mu \mathrm{m}$ long (mean $3.58 \pm 0.88 \mu \mathrm{m}, n=15$ ) and $0.28-0.48 \mu \mathrm{m}$ wide (mean $0.42 \pm 0.06 \mu \mathrm{m}, n=15)$, some of which produced a stalk(s). When present, the stalk was more generally cylindrical and extended centrally along the cell axis from one pole. This stalk showed constriction sites distributed equally all along the tube, but which did not correspond to compartmenta- 


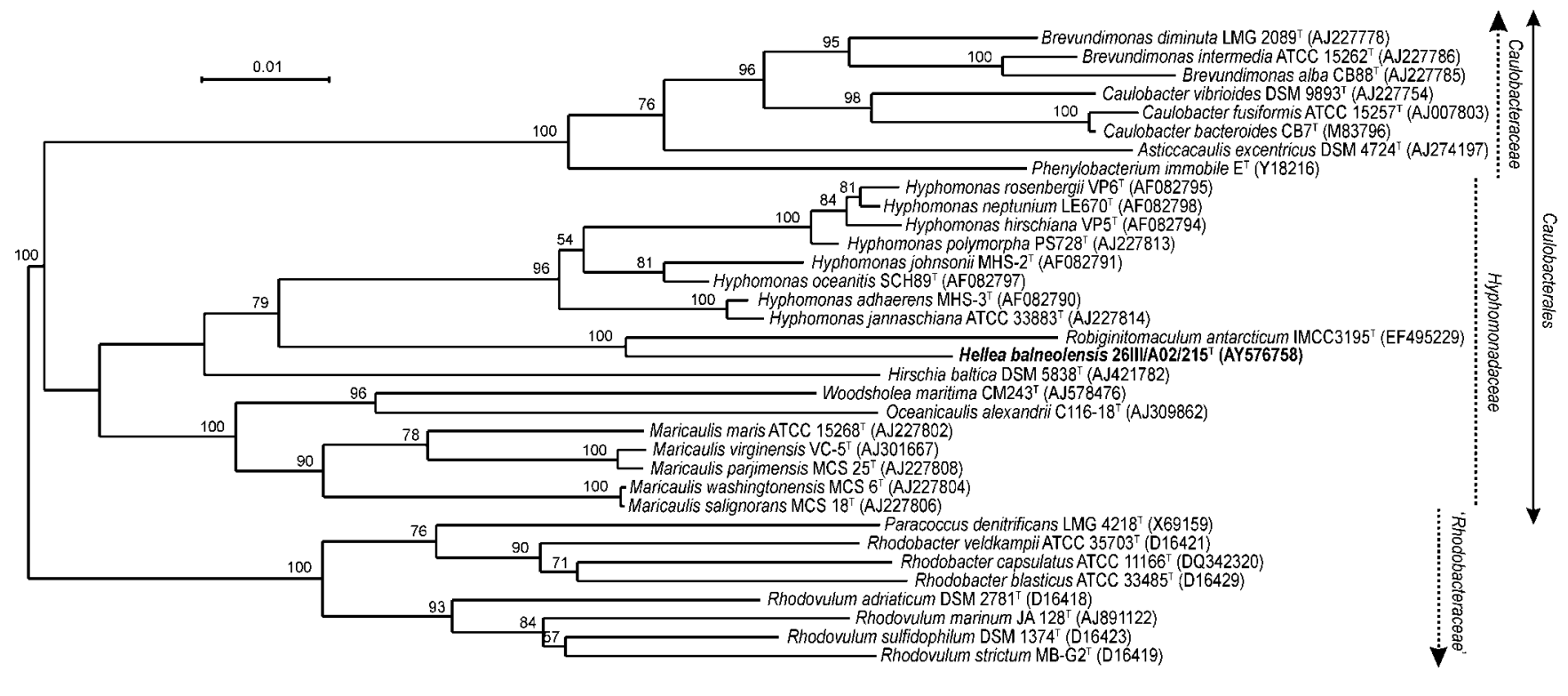

Fig. 1. Phylogenetic tree based on $16 \mathrm{~S}$ rRNA gene sequences showing the position of strain $26 \mathrm{Ill} / \mathrm{A} 02 / 215^{\top}$ within the order Caulobacterales (as outlined in this article), class Alphaproteobacteria. The alignment was performed with 16S rRNA gene sequences of related species. Sequence data for reference strains were obtained from the GenBank/EMBL and/or RDP databases. Accession numbers are indicated in parentheses. The topology shown corresponds to an unrooted tree obtained by the neighbour-joining algorithm, established using the PHYLIP package. Bootstrap values (from 1000 replicates) are indicated at branch nodes. The positioning of the novel isolate was confirmed by the maximum-likelihood method. Bar, 1 substitution per 100 nucleotide positions.

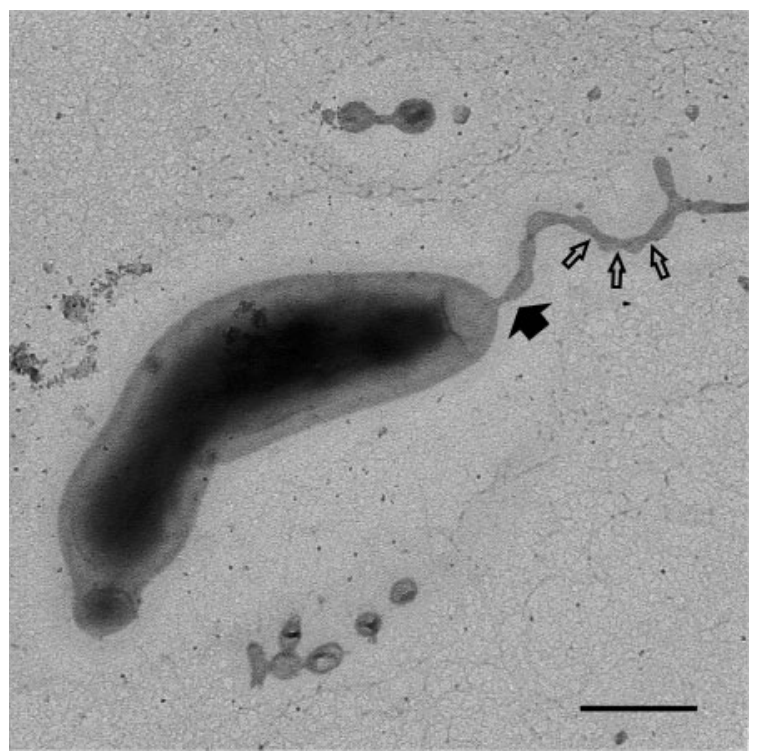

Fig. 2. Transmission electron micrograph of a budding cell of strain $26 I I / / A 02 / 215^{\top}$ negatively stained with uranyl acetate. It can be observed that the products of the cell division are unequal (simple budding). The cell bears a polar stalk (black arrow), which is an open ring constricted regularly on its length (open arrows). Bar, $0.5 \mu \mathrm{m}$. lization. This type of constriction has been observed previously in Oceanicaulis alexandrii (Strömpl et al., 2003). Stalked cells were non-motile, while non-stalked cells were motile by means of a polar flagellum. Cells divided by budding.

In order to analyse respiratory quinones and polar lipids, strain 26III/A02/215 ${ }^{\mathrm{T}}$ was grown for 3 days in MB medium at $30{ }^{\circ} \mathrm{C}$ and checked for purity. Initial analyses of the polar lipids and respiratory quinones were carried out by the Identification Service of the DSMZ. Ubiquinone (Q-10) was determined to be the sole respiratory quinone. The TLC plate obtained with cell extracts from the novel isolate was very characteristic (Fig. 3). The polar lipid pattern showed the presence of phosphatidylglycerol, monoglycosyldiglyceride, glucuronopyranosyldiglyceride, an unidentified glycolipid (GL) and three phospholipids (PL1, PL2, PL3). The presence of the polar lipids monoglycosyldiglyceride and glucuronopyranosyldiglyceride appears to be a characteristic signature for other members of the families Hyphomonadaceae and Caulobacteraceae, together with the absence of phosphatidylethanolamine, phosphatidylcholine and diphosphatidylglycerol. The presence of two unidentified phospholipids, PL2 and PL3, together with an unidentified glycolipid appeared to be a characteristic feature of the lipid pattern of this taxon. The determination of the whole-cell fatty acid composition was performed on cultures grown at $30{ }^{\circ} \mathrm{C}$ for $72 \mathrm{~h}$ on MA. The analysis was carried out at the DSMZ according to the standard 


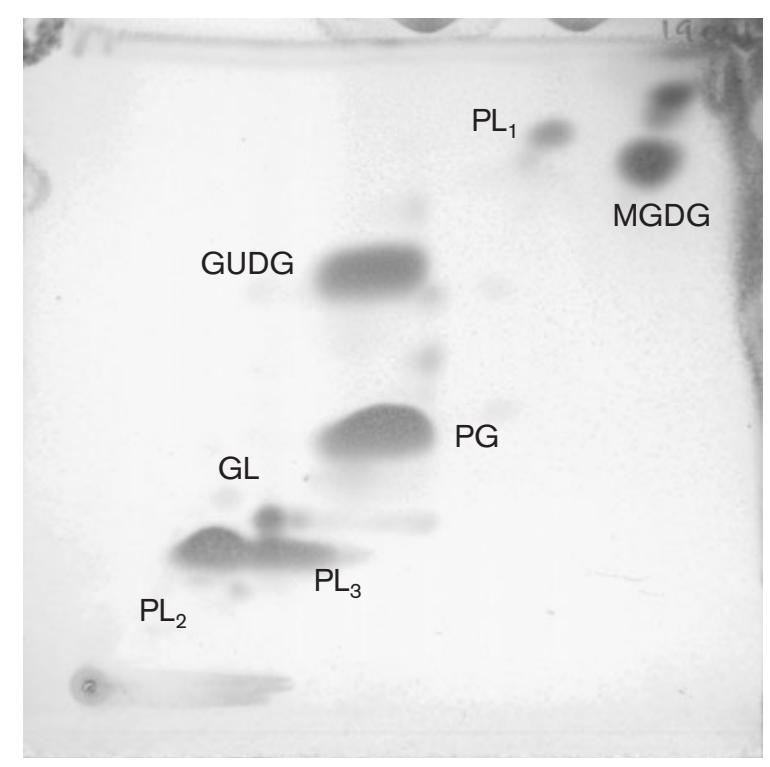

Fig. 3. Polar lipids of strain $26 \mathrm{Ill} / \mathrm{A} 02 / 215^{\top}$ following separation by two-dimensional TLC. PG, Phosphatidylglycerol; PL1, PL2, PL3, phospholipids; GL, unidentified glycolipid; MGDG, monoglycosyldiglyceride; GUDG, glucuronopyranosyldiglyceride.

protocol of the Microbial Identification System (MIDI, 2001). Extracts were analysed using a Hewlett Packard model HP6890A gas chromatograph equipped with a flame-ionization detector as described by Kämpfer \& Kroppenstedt (1996). Results are summarized in Table 1. The fatty acids in strain $2611 \mathrm{I} / \mathrm{A} 02 / 215^{\mathrm{T}}$ comprised $\mathrm{C}_{16: 0}$, $\mathrm{C}_{17: 0}, \quad \mathrm{C}_{18: 0}, \quad \mathrm{C}_{19: 0}, \quad \mathrm{C}_{17: 1} \omega 8 c, \quad \mathrm{C}_{17: 1} \omega 6 c, \mathrm{C}_{18: 1} \omega 9 c$, $\mathrm{C}_{18: 1} \omega 7 c, \mathrm{C}_{20: 1} \omega 7 c, 3-\mathrm{OH} \mathrm{C}_{10: 0}, 3-\mathrm{OH} \mathrm{C}_{11: 0}, 3-\mathrm{OH}$ $\mathrm{C}_{12: 1}, 2-\mathrm{OH} \mathrm{C} \mathrm{C}_{18: 1}$, tuberculostearic acid (TBSA; 10-methyl $\mathrm{C}_{18: 0}$ ), summed feature 3 and summed feature 7 . The presence of $\mathrm{C}_{18: 1} \omega 7 c$ together with Q-10 is typical of the vast majority of taxa within the Alphaproteobacteria. Although the polar lipid composition of the recently described Robiginitomaculum antarcticum was not reported, there were clear differences in the fatty acid patterns, in particular the distribution of the $3-\mathrm{OH}$ fatty acids, which are probably derived from lipopolysaccharide. A number of recent publications are also not complete with regard to chemotaxonomic data. In papers on the genera Oceanicaulis (Strömpl et al., 2003) and Woodsholea (Abraham et al., 2004) and some Maricaulis (Abraham et al., 2002) species, the quinone composition has not been reported. In the case of Oceanicaulis, 3-OH fatty acids are not reported, probably because only fatty acids from extracted lipids have been reported. Reports on the polar lipid composition may be incomplete because emphasis has been placed on the presence of phosphate- and sulfonic acid-containing lipids (Strömpl et al., 2003; see also Abraham et al., 1997). The glycolipids that are otherwise characteristic for this evolutionary group are not mentioned.
Table 1. Whole-cell fatty acid profile of strain $26 \mathrm{III} / \mathrm{A} 02 / 215^{\top}$ cultivated on MA

Values are percentages of the fatty acids that were assigned to fatty acids in the peak-naming table of the MIS database (MIDI, 2001); only $62 \%$ of the fatty acid peaks could be assigned, and unknown components displaying ECL (equivalent chain-length) values of $16.760,17.608,18.116,18.585,18.797$ and 19.347 were detected. The nomenclature is as follows: the first number indicates the number of carbon atoms in the molecule; 'iso', 'OH' and 'cyclo' indicate isobranched, hydroxy or cyclic fatty acids; the second number following the colon indicates the number of double bonds present. The position of the double bond is indicated by the carbon atom position starting from the methyl $(\omega)$ end of the molecule. $c$, cis isomer. Major fatty acids are indicated in bold.

\begin{tabular}{|c|c|}
\hline Fatty acid & Proportion (\%) \\
\hline \multicolumn{2}{|l|}{ Saturated } \\
\hline $\mathrm{C}_{16: 0}$ & 0.98 \\
\hline $\mathrm{C}_{17: 0}$ & 5.63 \\
\hline $\mathrm{C}_{18: 0}$ & 1.81 \\
\hline $\mathrm{C}_{19: 0}$ & 0.79 \\
\hline \multicolumn{2}{|l|}{ Monounsaturated } \\
\hline $\mathrm{C}_{17: 1} \omega 8 c$ & 2.18 \\
\hline$C_{17: 1} \omega 6 c$ & 6.60 \\
\hline $\mathrm{C}_{18: 1} \omega 9 c$ & 1.06 \\
\hline $\mathrm{C}_{18: 1} \omega 7 c$ & 67.22 \\
\hline $\mathrm{C}_{20: 1} \omega 7 c$ & 0.68 \\
\hline \multicolumn{2}{|l|}{ Hydroxy } \\
\hline $2-\mathrm{OH} \mathrm{C} 18: 1$ & 2.51 \\
\hline $3-\mathrm{OH} \mathrm{C} \mathrm{C}_{10: 0}$ & 2.23 \\
\hline $3-\mathrm{OH} \mathrm{C} \mathrm{C}_{11: 0}$ & 0.92 \\
\hline $3-\mathrm{OH} \mathrm{C} \mathrm{C}_{12: 1}$ & 1.23 \\
\hline \multicolumn{2}{|l|}{ Methyl-substituted } \\
\hline TBSA & 1.39 \\
\hline \multicolumn{2}{|l|}{ Summed features } \\
\hline Summed feature $3^{*}$ & 0.66 \\
\hline Summed feature $7^{\star}$ & 4.11 \\
\hline
\end{tabular}

${ }^{\star}$ Summed feature 3 contains $\mathrm{C}_{16: 1} \omega 7 c$ and/or $2-\mathrm{OH}$ iso- $\mathrm{C}_{15: 0}$ and summed feature 7 contains one or more of $\mathrm{C}_{19: 0}$ cyclo $\omega 10 c$, $\mathrm{C}_{19: 1} \omega 6 c$ and/or unknown ECL 18.846.

Unless stated otherwise, physiological characterization was carried out aerobically in $\mathrm{MB}$ in triplicate and the cell suspension was incubated with agitation in the dark. Growth was monitored routinely by measuring the increase in optical density at $600 \mathrm{~nm}$ using a spectrophotometer. Cell numbers were determined by flow cytometry (Marie et al., 2000) in order to calculate calibration curves 'cell number $=f\left(\mathrm{OD}_{600}\right)$ '. Growth rates were calculated using linear regression analysis from five to nine points along the logarithmic portions of the resulting growth curves. Growth was tested at $9,15,20,25,30,33,37$ and $44{ }^{\circ} \mathrm{C}$. The novel isolate was found to be mesophilic, growing at $15-37{ }^{\circ} \mathrm{C}$; optimal growth yields occurred at $30{ }^{\circ} \mathrm{C}$ (see Supplementary Fig. S1 available in IJSEM Online). The optimum $\mathrm{pH}$ for growth was tested at $30{ }^{\circ} \mathrm{C}$ in buffered 
$\mathrm{MB}$ and was found to be around $\mathrm{pH}$ 6.0-8.0. Salt tolerance was tested at $30{ }^{\circ} \mathrm{C}$ in $\mathrm{MB}$ prepared with various concentrations of $\mathrm{NaCl}(0.02,0.5,1,2,3,4,5,6,7$ and $9 \% \mathrm{w} / \mathrm{v})$. Results indicated that the strain was a typical marine-type halophile. Growth was observed in media containing $0.02-5 \%(\mathrm{w} / \mathrm{v}) \mathrm{NaCl}$, but it was better in media containing half- to full-strength seawater salinity. The optimal $\mathrm{NaCl}$ concentration for growth was around $3 \%$ (w/v) $\mathrm{NaCl}$.

Strain 26III/A02/215 $5^{\mathrm{T}}$ was found to be aerobic. Conventional phenotypic tests including those for oxidase, catalase, Tween esterase and nitrate reductase were performed according to standard methods (Smibert \& Krieg, 1994). Biochemical tests were performed at $30{ }^{\circ} \mathrm{C}$ using API ZYM (bioMérieux) and Biolog GN2 microplates (Oxoid). These tests were inoculated with cells grown on MA plates, swabbed from the surface of the agar plates and then suspended in ASW $1 / 2$ (diluted artificial seawater) to the density specified by the manufacturer. Supplementary biochemical tests were also performed using API 20NE strips (bioMérieux), following the manufacturer's instructions. Testing for oxidation of carbon sources with Biolog GN2 plates indicated that the strain was able to oxidize a wide range of organic acids and amino acids. To confirm these results and to test for the capacity of the strain to catabolize different substrates as sole carbon and energy sources with oxygen as a terminal electron acceptor, the strain was grown aerobically, in the dark, on a mineral medium supplemented with one substrate. The defined medium (modified from Widdel et al., 2006) had the following composition $\left(\mathrm{l}^{-1}\right)$ : phosphate buffer, $30 \mathrm{mM}$; $\mathrm{NaCl}, 20 \mathrm{~g} ; \mathrm{MgCl}_{2} \cdot 6 \mathrm{H}_{2} \mathrm{O}, 3 \mathrm{~g} ; \mathrm{CaCl}_{2} \cdot 2 \mathrm{H}_{2} \mathrm{O}, 1.0 \mathrm{~g} ; \mathrm{NH}_{4} \mathrm{Cl}$, $0.3 \mathrm{~g} ; \mathrm{KCl}, 0.5 \mathrm{~g} ; \mathrm{Na}_{2} \mathrm{SO}_{4}, 3 \mathrm{~g} ; \mathrm{NaNO}_{3}, 1 \mathrm{~g}$; trace element solution, $1 \mathrm{ml}$; selenite-tungstate solution, $1 \mathrm{ml}$; vitamin solution, $1 \mathrm{ml}$. The strain was found to grow heterotrophically on a wide range of substrates. It catabolized organic acids, amino acids and complex substrates for energy and growth. The carbohydrates tested were unable to support growth when provided alone in the medium. The results of the phenotypic characterization are given in the species description and Table 2.

Antibiotic sensitivity tests were performed by using susceptibility discs (Bio-Rad) or filter-paper discs impregnated with different antibiotics. Discs were placed on MA plates spread with a culture of the isolate and were then incubated at $30{ }^{\circ} \mathrm{C}$ for 1 week. Susceptibility was scored as positive at zone diameters above $10 \mathrm{~mm}$ (Table 2).

During the course of this work, we have also had cause to re-examine the taxonomy of members of the families Hyphomonadaceae and Caulobacteraceae. The placement of members of the genera Hyphomonas, Hirschia, Maricaulis and Oceanicaulis in the family Rhodobacteraceae (Garrity et al., 2005a) has been called into question by Lee et al. (2005). Independent work on the genome of Hyphomonas neptunium has indicated that the $16 \mathrm{~S}$ rRNA gene sequencebased interpretation may be prone to error (Badger et al.,
Table 2. Phenotypic and genotypic characteristics of strain $26 I I I / A 02 / 215^{\top}$

+ , Positive; -, negative; w, weakly positive; ND, not determined; vs, very susceptible (diameter of inhibition zone $>20 \mathrm{~mm}$ ); s, susceptible (diameter of inhibition zone: $10-20 \mathrm{~mm}$ ).

\begin{tabular}{|c|c|}
\hline Characteristic & Result \\
\hline \multicolumn{2}{|l|}{ API ZYM/API 20NE tests } \\
\hline Alkaline phosphatase & + \\
\hline Esterase & + \\
\hline Esterase lipase & + \\
\hline Naphthol-AS-BI-phosphohydrolase & + \\
\hline$\beta$-Galactosidase & + \\
\hline Urease & - \\
\hline Nitrate reductase & - \\
\hline Hydrolysis of aesculin ( $\beta$-glucosidase $)$ & + \\
\hline Hydrolysis of gelatin & - \\
\hline Glucose fermentation & - \\
\hline \multicolumn{2}{|l|}{$\begin{array}{l}\text { Oxidation (Biolog)/utilization as sole carbon and } \\
\text { energy source (minimal mineral medium) of: }\end{array}$} \\
\hline Acetic acid, citric acid & $+1+$ \\
\hline cis-Aconitic acid & $+/ \mathrm{ND}$ \\
\hline D-Glucuronic acid & $+/ \mathrm{ND}$ \\
\hline$\beta$ - and $\gamma$-Hydroxybutyric acids & $+/ \mathrm{ND}$ \\
\hline$\alpha$-Ketoglutaric acid & $+/ \mathrm{ND}$ \\
\hline Propionic acid, pyruvic acid, succinic acid & $+1+$ \\
\hline Methyl pyruvate & $+/ \mathrm{ND}$ \\
\hline Quinic acid & $+/ \mathrm{ND}$ \\
\hline Urocanic acid & $+/ \mathrm{ND}$ \\
\hline $\begin{array}{l}\text { L-Aspartic acid, L-glutamic acid, L-alanine, } \\
\text { L-asparagine, L-histidine, L-proline }\end{array}$ & $+1+$ \\
\hline L-Pyroglutamic acid, hydroxy-L-proline & $+/ \mathrm{ND}$ \\
\hline Putrescine & $+/ \mathrm{ND}$ \\
\hline Casamino acids & $\mathrm{ND} /+$ \\
\hline Peptone, tryptone, yeast extract & $\mathrm{ND} /+$ \\
\hline$N$-Acetylglucosamine & $+/ \mathrm{ND}$ \\
\hline D-Arabitol, myo-inositol & $+/ \mathrm{ND}$ \\
\hline D-Mannitol & $+1+$ \\
\hline Xylitol & $+/ \mathrm{ND}$ \\
\hline Dextrin, D-mannose, cellobiose & $\mathrm{W} / \mathrm{ND}$ \\
\hline$\alpha$-D-Glucose, starch & $\mathrm{w} / \mathrm{w}$ \\
\hline \multicolumn{2}{|l|}{ Susceptibility to ( $\mu \mathrm{g}$ per disc): } \\
\hline $\begin{array}{l}\text { Ciprofloxacin (100), rifampicin (100), } \\
\text { vancomycin }(100)\end{array}$ & vs \\
\hline Oxacillin (5), penicillin (6), tetracycline (100) & s \\
\hline
\end{tabular}

2005, 2006). This conclusion is also in accord with the chemical composition reported for members of these genera, which share a number of distinctive similarities with members of the genera Caulobacter, Brevundimonas, Asticcacaulis and Phenylobacterium. Similarly, extensive chemotaxonomic work on additional taxa within the family Rhodobacteraceae as defined by Garrity et al. (2005a) would also indicate inconsistencies (Biebl et al., 2005a, b, 2006, 2007; Martens et al., 2006; Labrenz et al., $1999,2000)$ with the proposal of Lee et al. (2005) to unite members of the families Rhodobacteraceae (as defined by 
Lee et al., 2005), Hyphomonadaceae and Caulobacteraceae (as defined by Lee et al., 2005 and Garrity et al., 2005a). Clearly, the family Hyphomonadaceae should comprise the genera Hirschia, Hyphomonas, Maricaulis, Oceanicaulis, Woodsholea and Robiginitomaculum and the new taxon proposed here. It is interesting to note that this family may be subdivided into two groups, one with cells that divide by budding and the other by binary fission. In addition, there is some evidence that there may also be a correlation between the two groups and the polar lipid patterns, although additional work is needed to test this hypothesis. When such work is completed, it would be appropriate to emend the description and circumscription of the family Hyphomonadaceae Lee et al. 2005 in the light of chemotaxonomic data, bringing it into line with recommendations dating back to the ad hoc committee reports of Wayne et al. (1987) and Murray et al. (1990). A similar treatment of the family Caulobacteraceae, which comprises the genera Caulobacter, Brevundimonas, Asticcacaulis and Phenylobacterium, would be appropriate. The order Caulobacterales should also be restricted to include only the members of the families Caulobacteraceae and Hyphomonadaceae and its description emended accordingly. A further consequence would be that the members of the family Rhodobacteraceae as defined by Lee et al. (2005) should be formally assigned to a family that excludes the type of the family Hyphomonadaceae. Based on published chemotaxonomic data, it would also be prudent to test whether members of that taxon should be further divided into several families and all included in the order Rhodobacterales.

Briefly, the results of our genotypic, chemotaxonomic, morphological and physiological investigations, together with the phylogenetic analyses, revealed that strain 26III/ A02 $/ 215^{\mathrm{T}}$ is distinct from other members of the family Hyphomonadaceae. The main characteristics that differentiate the novel isolate from its closest phylogenetic neighbours are summarized in Table 3. In brief, the novel taxon can be distinguished from all its closest relatives, with the exception of members of the genus Hirschia, by its significantly lower $\mathrm{G}+\mathrm{C}$ content. The fatty acid composition and polar lipid composition represent other distinctive criteria between the new taxon and other members of the family. Although much emphasis is put on the 'major fatty acids' in the majority of recent taxonomic papers, we emphasize here the fact that the large amounts of $18: 1 \omega 7 c$ (together with the presence of Q-10) indicate only that this genus is a member of the Alphaproteobacteria and cannot be described as 'characteristic' of this or any other genus. In contrast, the sum of chemotaxonomic data not only places it clearly within the family Hyphomonadaceae, order Caulobacterales, but also provides a unique signature for this taxon within these higher taxa. In terms of other phenotypic features, differences in morphological characteristics such as the fine structure of the stalk, its position, the flagellation of the cells, the colonial pigmentation and the mode of division of the cells can also be used to distinguish the novel isolate from members of the genera Robiginitomaculum, Hyphomonas, Hirschia, Woodsholea, Oceanicaulis and Maricaulis (Table 3).

In conclusion, on the basis of the phylogenetic position and of genotypic, chemotaxonomic, physiological, biochemical and morphological differences, we propose that isolate $26 \mathrm{III} / \mathrm{A} 02 / 215^{\mathrm{T}}$ should be assigned as the type strain of a novel species within a new genus, for which the name Hellea balneolensis gen. nov., sp. nov. is proposed.

\section{Description of Hellea gen. nov.}

Hellea (Hel.le'a. L. fem. n. Helle a sea goddess in Greek mythology; N.L. fem. n. Hellea named after Helle in reference to the marine origin of the first strain).

Cells are Gram-negative, non-spore-forming, rod-shaped to vibrioid and dimorphic; they usually possess one polar stalk (prostheca) and are non-motile, or they are nonstalked and motile by means of a polar flagellum. Aerobic and heterotrophic. Mesophilic. Neutrophilic. Grow best at salt concentrations close to marine salinity. The predominant quinone is Q-10. Polar lipids comprise glucuronopyranosyldiglyceride, monoglycosyldiglyceride, phosphatidylglycerol and an unidentified glycolipid and phospholipids. Fatty acids comprise $\mathrm{C}_{16: 0}, \mathrm{C}_{17: 0}, \mathrm{C}_{18: 0}, \mathrm{C}_{19: 0}$, $\mathrm{C}_{17: 1} \omega 8 c, \mathrm{C}_{17: 1} \omega 6 c, \mathrm{C}_{18: 1} \omega 9 c, \mathrm{C}_{18: 1} \omega 7 c, \mathrm{C}_{20: 1} \omega 7 c, 3-\mathrm{OH}$ $\mathrm{C}_{10: 0}, 3-\mathrm{OH} \mathrm{C} \mathrm{C}_{11: 0}, 3-\mathrm{OH} \mathrm{C} \mathrm{C}_{12: 1}, 2-\mathrm{OH} \mathrm{C} \mathrm{C}_{18: 1}$, TBSA (10methyl $\mathrm{C}_{18: 0}$ ), summed feature 3 and summed feature 7 (percentage composition for the type strain of the type species is given in Table 1). The $\mathrm{G}+\mathrm{C}$ content of the DNA of the type strain of the type species is $46.8 \mathrm{~mol} \%$. The genus belongs to the class Alphaproteobacteria, order Caulobacterales, family Hyphomonadaceae, showing a distant relatedness to prosthecate bacteria of marine origin, namely members of the genera Hyphomonas, Robiginitomaculum, Hirschia, Woodsholea, Maricaulis and Oceanicaulis. The type species is Hellea balneolensis, currently the only species within the genus.

\section{Description of Hellea balneolensis sp. nov.}

Hellea balneolensis (bal.ne'o.len'sis. M.L. n. Balneola the ancient name of Banyuls-sur-mer; N.L. fem. adj. balneolensis pertaining to Balneola, from where the type strain was isolated).

In addition to the characters described for the genus, the species is characterized by the following properties. Colonies on MA medium are round, convex, brilliant and pigmented a brick-red colour. Optimal growth occurs at $30{ }^{\circ} \mathrm{C}$, with growth at $15-37^{\circ} \mathrm{C}$. The $\mathrm{pH}$ optimum is close to neutrality. Grows at $\mathrm{NaCl}$ concentrations of 0.02 $5 \%(\mathrm{w} / \mathrm{v})$, with a clear optimum at $3 \%(\mathrm{w} / \mathrm{v}) \mathrm{NaCl}$. Growth occurs on acetate, citrate, propionate, pyruvate, succinate, aspartate, glutamate, L-alanine, L-asparagine, Lhistidine, L-proline, Casamino acids, peptone, tryptone, yeast extract and D-mannitol. Substrates positive in Biolog GN2 plates are all the substrates cited above as well as cis- 
Table 3. Characteristics that differentiate Hellea gen. nov. from related genera of the family Hyphomonadaceae

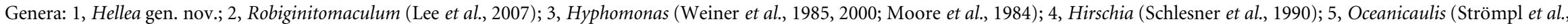

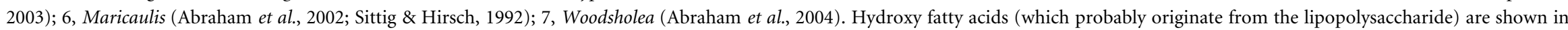
bold. Fatty acids indicated in parentheses are found in some strains. v, Variable; $(+)$, some strains grow under these conditions; ND, no data available.

\begin{tabular}{|c|c|c|c|c|c|c|c|}
\hline Characteristic & 1 & 2 & 3 & 4 & 5 & 6 & 7 \\
\hline Colony colour & Brick red & Rusty-orange & Grey or colourless ${ }^{*}$ & Yellow & Colourless & Colourless & Colourless \\
\hline Prostheca(e) & One, polar & One, polar & One to two, polar & One to two, polar & One, polar & One, polar & One, polar \\
\hline Stalk cross wall & + & - & - & - & + & - & + \\
\hline Mode of division & Budding & Binary fission & Budding & Budding & Binary fission & Binary fission & Binary fission \\
\hline Flagellation & Monotrichous, polar & Absent & One to three, polar & Monotrichous, polar & Monotrichous, polar & Monotrichous, polar & Monotrichous, polar \\
\hline Nitrate reduction & - & + & + & - & + & $(+)$ & - \\
\hline Growth at $6 \% \mathrm{NaCl}$ & - & - & $\mathrm{V}$ & ND & + & $(+)$ & + \\
\hline Polar lipids $\dagger$ & $\begin{array}{l}\text { PG, MGDG, GUDG, } \\
\text { GL, } \mathrm{PL}_{1}, \mathrm{PL}_{2}, \mathrm{PL}_{3}\end{array}$ & ND & $\begin{array}{l}\text { MGDG, GUDG, } \\
\text { PG, Tau }\end{array}$ & $\begin{array}{l}\text { MGDG, GUDG, } \\
\text { PG, GL } \ddagger\end{array}$ & $\begin{array}{l}\text { PG, SQDG [MGDG, } \\
\text { GUDG]\$ }\end{array}$ & $\begin{array}{l}\text { PG, SQDG, Tau, } \\
\text { MGDG, GUDG }\end{array}$ & $\begin{array}{l}\text { SQDG, Tau, MGDG, } \\
\text { GUDG }\end{array}$ \\
\hline Major fatty acids & $\begin{array}{l}\text { 3-OH C } \mathbf{1 0 : 0}, \mathbf{3 - O H} \\
\mathbf{C}_{\mathbf{1 2 : 1}}, \mathbf{3}-\mathbf{O H} \mathrm{C}_{\mathbf{1 1 : 0}} \\
\mathrm{C}_{17: 1} \omega 6 c, \mathrm{C}_{17: 1} \omega 8 c \\
\mathrm{C}_{18: 1} \omega 7 c, \mathrm{C}_{17: 0}\end{array}$ & $\begin{array}{l}\text { 3-OH C } \mathbf{C}_{9: 0}, \mathbf{3 - O H} \\
\mathbf{C}_{10: 0}, \mathbf{3}-\mathbf{O H} \mathrm{C}_{11: 0}, \\
\mathrm{C}_{15: 1} \omega 8 c, \mathrm{C}_{15: 1} \omega 6 c, \\
\mathrm{C}_{15: 0}, \mathrm{C}_{16: 0}, \\
\mathrm{C}_{16: 1} \omega 9 c, \mathrm{C}_{16: 1} \omega 7 c, \\
\mathrm{C}_{17: 1} \omega 8 c, \mathrm{C}_{17: 0}, \\
\mathrm{C}_{17: 1} \omega 6 c, \mathrm{C}_{18: 0}, \\
\mathrm{C}_{18: 1} \omega 7 c, \mathrm{C}_{18: 1} \omega 9 c\end{array}$ & $\begin{array}{l}\text { 3-OH C } \mathrm{C}_{12: 0}, 3-\mathbf{O H} \\
\mathrm{C}_{12: 1},\left(\mathrm{C}_{15: 0}\right) \\
\mathrm{C}_{16: 0}, \mathrm{C}_{17: 1} \omega 811 \\
\left(\mathrm{C}_{17: 1} \omega 6\right), \mathrm{C}_{17: 0} \\
\mathrm{C}_{18: 1} \omega 7, \\
11-\mathrm{Me}_{18: 1} \omega 6, \\
\mathrm{C}_{19: 1} \omega 8\end{array}$ & $\begin{array}{l}\text { 3-OH C } \mathbf{C}_{12: 0}, 3-\mathbf{O H} \\
\mathrm{C}_{14: 1}, \mathrm{C}_{16: 1} \omega 11 c \\
\mathrm{C}_{16: 1} \omega 7 c, \mathrm{C}_{16: 0} \\
\mathrm{C}_{18: 0}, \mathrm{C}_{18: 1} \omega 7 c \\
\mathrm{C}_{18: 2} \omega 7\end{array}$ & $\begin{array}{l}\text { 3-OH FAMES\#, } \\
\mathrm{C}_{16: 0}, \mathrm{C}_{17: 1} \omega 6, \\
\mathrm{C}_{17: 0}, \mathrm{C}_{18: 1} \omega 7, \\
\mathrm{C}_{18: 0}, 7-\mathrm{Me} \\
\mathrm{C}_{18: 1} \omega 6, \mathrm{C}_{19: 0}{ }^{* *}\end{array}$ & $\begin{array}{l}\text { 3-OH iso- } \mathrm{C}_{11: 0}, \\
\mathrm{C}_{16: 0}, \mathrm{C}_{17: 0} \\
\mathrm{C}_{16: 1} \omega 7 c \#, \text { iso } \\
\mathrm{C}_{17: 0}, \text { iso- } \mathrm{C}_{17: 1} \omega 9 c, \\
\mathrm{C}_{17: 1} \omega 6 c, \mathrm{C}_{17: 1} \omega 8 c, \\
\mathrm{C}_{18: 1} \omega 7 c \#, \mathrm{C}_{18: 1} \omega 9 c\end{array}$ & $\begin{array}{l}\text { 3-OH C } \mathrm{C}_{12: 0}, \mathrm{C}_{16: 0} \\
\mathrm{C}_{17: 0}, \mathrm{C}_{18: 0} \\
\mathrm{C}_{18: 1} \omega 7 c\end{array}$ \\
\hline Quinone(s) & Q-10 & $\mathrm{ND}$ & Q-10 or Q-11 & Q-10 & ND & Q-10 & $\mathrm{ND}$ \\
\hline $\begin{array}{l}\text { DNA G }+C \text { content } \\
(\mathrm{mol} \%)\end{array}$ & 47 & 60 & $57-64$ & $45-47$ & $61-62$ & $62-65$ & 65 \\
\hline
\end{tabular}

${ }^{\star}$ May produce a water-soluble brown/red-brown pigment.

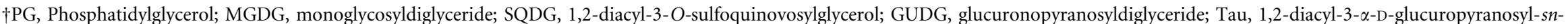
glycerol taurineamide; PL, unidentified phospholipid; GL, unidentified glycolipids.

$¥$ B. J. Tindall, unpublished.

§The lipids MGDG and GUDG are not mentioned specifically, but the lipid fraction containing them was not investigated.

IIFatty acid nomenclature used in the original paper was the $\Delta$ nomenclature; this has been converted to the $\omega$ nomenclature in this table. cis- or trans-isomers were not specified.

SHydroxylated fatty acids not mentioned, but only the fatty acids from a polar lipid fraction were examined.

\#Data from Abraham et al. ( 2004).

${ }^{* *}$ cis- or trans-isomers not specified. 
aconitic acid, D-glucuronic acid, $\beta$-hydroxybutyric acid, $\gamma$ hydroxybutyric acid, $\alpha$-ketoglutaric acid, methyl pyruvate, quinic acid, urocanic acid, L-pyroglutamic acid, hydroxy-Lproline, putrescine, $\mathrm{N}$-acetylglucosamine, D-arabitol, myoinositol and xylitol. Does not reduce nitrate. Catalasepositive and oxidase-negative. Tween 40 and Tween 80 hydrolysis activities are positive.

The type strain, $26 \mathrm{III} / \mathrm{A} 02 / 215^{\mathrm{T}}\left(=\mathrm{DSM} 19091^{\mathrm{T}}=\mathrm{CIP}\right.$ $109500^{\mathrm{T}}=\mathrm{OOB} 269^{\mathrm{T}}$ ), was isolated from the surface microlayer of coastal water in the bay of Banyuls-sur-mer, in the north-western Mediterranean Sea on the coast of France $\left(42^{\circ} 29^{\prime} \mathrm{N}^{\circ} 08^{\prime} \mathrm{E}\right)$.

\section{Acknowledgements}

We thank Marie-Line Escande for assistance with the transmission electron microscopy and Hélène Agogue for her contribution to the initial sequencing work. We acknowledge Dr J. P. Euzéby for support in the Latin etymologies of the genus and species names. This work was supported financially by the Equipe Mixte de Recherche linking the Université Pierre et Marie Curie and the Centre National de la Recherche Scientifique to the Pierre Fabre Laboratories. The project was also carried out in the framework of the MarBEF Network of Excellence 'Marine Biodiversity and Ecosystem Functioning' which is funded by the Sustainable Development, Global Change and Ecosystems Program of the European Community's Sixth Framework Program (contract no. GOCE-CT-2003-505446). This publication is contribution number MPS-07059 of MarBEF. It was also partly funded by the French program 'Bio-diversité et Changement Global - project: development of a coastal microbial observatory' from the Institut Français de la Biodiversité.

\section{References}

Abraham, W.-R., Meyer, H., Lindholst, S., Vancanneyt, M. \& Smit, J. (1997). Phospho- and sulfolipids as biomarkers of Caulobacter sensu lato, Brevundimonas and Hyphomonas. Syst Appl Microbiol 20, 522539.

Abraham, W.-R., Strömpl, C., Meyer, H., Lindholst, S., Moore, E. R. B., Christ, R., Vancanneyt, M., Tindall, B.-J., Bennasar, A. \& other authors (1999). Phylogeny and polyphasic taxonomy of Caulobacter species. Proposal of Maricaulis gen. nov. with Maricaulis maris (Poindexter) comb. nov. as the type species, and emended description of the genera Brevundimonas and Caulobacter. Int J Syst Bacteriol 49, 1053-1073.

Abraham, W.-R., Strömpl, C., Bennasar, A., Vancanneyt, M., Snauwaert, C., Swings, J., Smit, J. \& Moore, E. R. B. (2002). Phylogeny of Maricaulis Abraham et al. 1999 and proposal of Maricaulis virginensis sp. nov., M. parjimensis sp. nov., M. washingtonensis sp. nov. and M. salignorans sp. nov. Int J Syst Evol Microbiol 52, 21912201.

Abraham, W.-R., Strömpl, C., Vancanneyt, M., Bennasar, A., Swings, J., Lünsdorf, H., Smit, J. \& Moore, E. R. B. (2004). Woodsholea maritima gen. nov., sp. nov., a marine bacterium with a low diversity of polar lipids. Int J Syst Evol Microbiol 54, 1227-1234.

Agogué, H., Casamayor, E. O., Bourrain, M., Obernosterer, I., Joux, F., Herndl, G. J. \& Lebaron, P. (2005). A survey on bacteria inhabiting the sea surface microlayer of coastal ecosystems. FEMS Microbiol Ecol 54, 269-280.

Altschul, S. F., Gish, W., Miller, W., Myers, E. W. \& Lipman, D. J. (1990). Basic local alignment search tool. J Mol Biol 215, 403-410.
Anast, N. \& Smit, J. (1988). Isolation and characterization of marine caulobacters and assessment of their potential for generic experimentation. Appl Environ Microbiol 54, 809-817.

Badger, J. H., Eisen, J. A. \& Ward, N. L. (2005). Genomic analysis of Hyphomonas neptunium contradicts $16 \mathrm{~S}$ rRNA gene-based phylogenetic analysis: implications for the taxonomy of the orders 'Rhodobacterales' and Caulobacterales. Int J Syst Evol Microbiol 55, 1021-1026.

Badger, J. H., Hoover, T. R., Brun, Y. V., Weiner, R. M., Laub, M. T., Alexandre, G., Mrázek, J., Ren, Q., Paulsen, I. T. \& other authors (2006). Comparative genomic evidence for a close relationship between the dimorphic prosthecate bacteria Hyphomonas neptunium and Caulobacter crescentus. J Bacteriol 188, 6841-6850.

Biebl, H., Allgaier, M., Tindall, B. J., Koblizek, M., Lünsdorf, H., Pukall, R. \& Wagner-Döbler, I. (2005a). Dinoroseobacter shibae gen. nov., sp. nov., a new aerobic phototrophic bacterium isolated from dinoflagellates. Int J Syst Evol Microbiol 55, 1089-1096.

Biebl, H., Allgaier, M., Lünsdorf, H., Pukall, R., Tindall, B. J. \& Wagner-Döbler, I. (2005b). Roseovarius mucosus sp. nov., a member of the Roseobacter clade with trace amounts of bacteriochlorophyll $a$. Int J Syst Evol Microbiol 55, 2377-2383.

Biebl, H., Tindall, B. J., Pukall, R., Lünsdorf, H., Allgaier, M. \& Wagner-Döbler, I. (2006). Hoeflea phototrophica sp. nov., a novel marine aerobic alphaproteobacterium that forms bacteriochlorophyll a. Int J Syst Evol Microbiol 56, 821-826.

Biebl, H., Pukall, R., Lünsdorf, H., Schulz, S., Allgaier, M., Tindall, B. J. \& Wagner-Döbler, I. (2007). Description of Labrenzia alexandrii gen. nov., sp. nov., a novel alphaproteobacterium containing bacteriochlorophyll $a$, and a proposal for reclassification of Stappia aggregata as Labrenzia aggregata comb. nov., of Stappia marina as Labrenzia marina comb. nov. and of Stappia alba as Labrenzia alba comb. nov., and emended descriptions of the genera Pannonibacter, Stappia and Roseibium, and of the species Roseibium denhamense and Roseibium hamelinense. Int J Syst Evol Microbiol 57, 1095-1107.

Felsenstein, J. (1981). Evolutionary trees from DNA sequences: a maximum likelihood approach. J Mol Evol 17, 368-376.

Felsenstein, J. (1985). Confidence limits on phylogenies: an approach using the bootstrap. Evolution 39, 783-791.

Galtier, N., Gouy, M. \& Gautier, C. (1996). SEAVIEW and PHYLO_WIN: two graphic tools for sequence alignment and molecular phylogeny. Comput Appl Biosci 12, 543-548.

Garrity, G. M. \& Holt, J. G. (2001). The road map to the Manual. In Bergey's Manual of Systematic Bacteriology, 2nd edn, vol. 1, pp. 119166. Edited by D. R. Boone, R. W. Castenholz \& G. M. Garrity. New York: Springer.

Garrity, G. M., Bell, J. A. \& Lilburn, T. (2005a). Class I. Alphaproteobacteria class. nov. In Bergey's Manual of Systematic Bacteriology, 2nd edn, vol. 2, part C, p. 1. Edited by D. J. Brenner, N. R. Krieg, J. T. Staley \& G. M. Garrity. New York: Springer.

Garrity, G. M., Bell, J. A. \& Lilburn, T. (2005b). Order III. Rhodobacterales ord. nov. In Bergey's Manual of Systematic Bacteriology, 2nd edn, vol. 2, part C, p. 161. Edited by D. J. Brenner, N. R. Krieg, J. T. Staley \& G. M. Garrity. New York: Springer.

Garrity, G. M., Bell, J. A. \& Lilburn, T. (2006). Rhodobacteraceae fam. nov. In List of New Names and New Combinations Previously Effectively, but not Validly, Published, Validation List no. 107. Int J Syst Evol Microbiol 56, 1-6.

Gieszczykiewicz, M. (1939). Zagadnienie systematihki w bakteriologii - Zur Frage der Bakterien-Systematic. Bull Acad Pol Sci Ser Sci Biol 1, 9-27 (in Polish with German abstract).

Henrici, A. T. \& Johnson, D. (1935). Stalked bacteria, a new order of schizomycetes. J Bacteriol 29, 3-4. 
Kämpfer, P. \& Kroppenstedt, R. M. (1996). Numerical analysis of fatty acid patterns of coryneform bacteria and related taxa. Can J Microbiol 42, 989-1005.

Kuykendall, L. D. (2005). Order VI. Rhizobiales ord. nov. In Bergey's Manual of Systematic Bacteriology, 2nd edn, vol. 2, part C, p. 324. Edited by D. J. Brenner, N. R. Krieg, J. T. Staley \& G. M. Garrity. New York: Springer.

Kwon, K. K., Lee, H.-S., Yang, S. H. \& Kim, S.-J. (2005). Kordiimonas gwangyangensis gen. nov., sp. nov., a marine bacterium isolated from marine sediments that forms a distinct phyletic lineage (Kordiimonadales ord. nov.) in the Alphaproteobacteria. Int J Syst Evol Microbiol 55, 2033-2037.

Labrenz, M., Collins, M. D., Lawson, P. A., Tindall, B. J., Schumann, P. \& Hirsch, P. (1999). Roseovarius tolerans gen. nov., sp. nov., a budding bacterium with variable bacteriochlorophyll a production from hypersaline Ekho Lake (Antarctica). Int J Syst Bacteriol 49, 137-147.

Labrenz, M., Tindall, B. J., Lawson, P. A., Collins, M. D., Schumann, P. \& Hirsch, P. (2000). Staleya guttiformis gen. nov., sp. nov. and Sulfitobacter brevis sp. nov., $\alpha$-3-Proteobacteria from hypersaline, heliothermal and meromictic antarctic Ekho Lake. Int J Syst Evol Microbiol 50, 303-313.

Lee, K.-B., Liu, C.-T., Anzai, Y., Kim, H., Aono, T. \& Oyaizu, H. (2005). The hierarchical system of the Alphaproteobacteria: description of Hyphomonadaceae fam. nov., Xanthobacteraceae fam. nov. and Erythrobacteraceae fam. nov. Int J Syst Evol Microbiol 55, 1907-1919.

Lee, K., Lee, H.-K., Choi, T.-H. \& Cho, J.-C. (2007). Robiginitomaculum antarcticum gen. nov., sp. nov., a member of the family Hyphomonadaceae, from Antarctic seawater. Int $J$ Syst Evol Microbiol 57, 2595-2599.

Marie, D., Simon, N., Guillou, L., Partensky, F. \& Vaulot, D. (2000). Flow cytometry analysis of marine picoplankton. In Living Color: Protocols in Flow Cytometry and Cell Sorting. Edited by R. A. Diamond \& S. DeMaggio, pp. 421-454. Berlin \& Heidelberg: Springer.

Martens, T., Heidorn, T., Pukall, R., Simon, M., Tindall, B. J. \& Brinkhoff, T (2006). Reclassification of Roseobacter gallaeciensis RuizPonte et al. 1998 as Phaeobacter gallaeciensis gen. nov., comb. nov., description of Phaeobacter inhibens sp. nov., reclassification of Ruegeria algicola (Lafay et al. 1995) Uchino et al. 1999 as Marinovum algicola gen. nov., comb. nov., and emended descriptions of the genera Roseobacter, Ruegeria and Leisingeria. Int J Syst Evol Microbiol 56, 1293-1304.

Mesbah, M., Premachandran, U. \& Whitman, W. B. (1989). Precise measurement of the $\mathrm{G}+\mathrm{C}$ content of deoxyribonucleic acid by highperformance liquid chromatography. Int J Syst Bacteriol 39, 159-167. MIDI (2001). Sherlock Microbial Identification System. Newark, DE: MIDI Inc.

Moore, R. L., Weiner, R. M. \& Gebers, R. (1984). Genus Hyphomonas Pongratz 1957 nom. rev. emend., Hyphomonas polymorpha Pongratz 1957 nom. rev. emend., and Hyphomonas neptunium (Leifson 1964) comb. nov. emend. (Hyphomicrobium neptunium). Int J Syst Bacteriol 34, 71-73.

Murray, R. G. E., Brenner, D. J., Colwell, R. R., De Vos, P., Goodfellow, M. Grimont, P. A. D., Pfennig, N., Stackebrandt, E. \& Zavarzin, G. A. (1990). Report of the ad hoc committee on approaches to taxonomy within the proteobacteria. Int J Syst Bacteriol 40, 213-215.
Pfenning, N. \& Trüper, H. G. (1971). Higher taxa of the phototrophic bacteria. Int J Syst Bacteriol 21, 17-18.

Poindexter, J. S. (1981). The caulobacters: ubiquitous unusual bacteria. Microbiol Rev 45, 123-179.

Raguénès, G., Christen, R., Guézennec, J., Pignet, P. \& Barbier, G. (1997). Vibrio diabolicus sp. nov., a new polysaccharide-secreting organism isolated from a deep-sea hydrothermal vent polychaete annelid, Alvinella pompejana. Int J Syst Bacteriol 47, 989-995.

Rosselló-Mora, R. \& Amann, R. (2001). The species concept for prokaryotes. FEMS Microbiol Rev 25, 39-67.

Saitou, N. \& Nei, M. (1987). The neighbor-joining method: a new method for reconstructing phylogenetic trees. Mol Biol Evol 4, 406425.

Schlesner, H., Bartels, C., Sittig, M., Dorsch, M. \& Stackebrandt, E. (1990). Taxonomic and phylogenetic studies on a new taxon of budding hyphal Proteobacteria, Hirschia baltica gen. nov., sp. nov. Int J Syst Bacteriol 40, 443-451.

Sittig, M. \& Hirsch, P. (1992). Chemotaxonomic investigation of budding and/or hyphal bacteria. Syst Appl Microbiol 15, 209-222.

Smibert, R. M. \& Krieg, N. R. (1994). Phenotypic characterization. In Methods for General and Molecular Bacteriology, pp. 607-655. Edited by P. Gerhardt, R. G. E. Murray, W. A. Wood \& N. R. Krieg. Washington, DC: American Society for Microbiology.

Strömpl, C., Hold, G. L., Lünsdorf, H., Graham, J., Gallacher, S., Abraham, W.-R., Moore, E. R. B. \& Timmis, K. N. (2003). Oceanicaulis alexandrii gen. nov., sp. nov., a novel stalked bacterium isolated from a culture of the dinoflagellate Alexandrium tamarense (Lebour) Balech. Int J Syst Evol Microbiol 53, 1901-1906.

Thompson, J. D., Gibson, T. J., Plewniak, F., Jeanmougin, F. \& Higgins, D. G. (1997). The CLUSTAL_X windows interface: flexible strategies for multiple sequence alignment aided by quality analysis tools. Nucleic Acids Res 25, 4876-4882.

Wayne, L. G., Brenner, D. J., Colwell, R. R., Grimont, P. A. D., Kandler, O., Krichevsky, M. I., Moore, L. H., Moore, W. E. C., Murray, R. G. E. \& other authors (1987). International Committee on Systematic Bacteriology. Report of the ad hoc committee on the reconciliation of approaches to bacterial systematics. Int J Syst Bacteriol 37, 463-464.

Weiner, R. M., Devine, R. A., Powell, D. M., Dagasan, L. \& Moore, R. L. (1985). Hyphomonas oceanitis sp. nov., Hyphomonas hirschiana sp. nov., and Hyphomonas jannaschiana sp. nov. Int J Syst Bacteriol 35, 237-243.

Weiner, R. M., Melick, M., O’Neill, K. \& Quintero, E. (2000). Hyphomonas adhaerens sp. nov., Hyphomonas johnsonii sp. nov. and Hyphomonas rosenbergii sp. nov., marine budding and prosthecate bacteria. Int J Syst Evol Microbiol 50, 459-469.

Widdel, F., Boetius, A. \& Rabus, R. (2006). Anaerobic biodegradation of hydrocarbons including methane. In The Prokaryotes: a Handbook on the Biology of Bacteria, 3rd edn, vol. 2, pp. 1028-1049. Edited by M. Dworkin, S. Falkow, E. Rosenberg, K. H. Schleifer \& E. Stackebrandt. New York: Springer.

Yabuuchi, E. \& Kosako, Y. (2005). Order IV. Sphingomonadales ord. nov. In Bergey's Manual of Systematic Bacteriology, 2nd edn, vol. 2, part C, pp. 230-233. Edited by D. J. Brenner, N. R. Krieg, J. T. Staley \& G. M. Garrity. New York: Springer. 